\title{
Kualitas Air dan Beban Limbah Karamba Jaring Apung di Waduk Jatiluhur Jawa Barat
}

[Water quality and wastewater load of floating net cages in Jatiluhur Reservoir of West Java]

\author{
Pigoselpi Anas, Iis Jubaedah, Dinno Sudino ${ }^{\bowtie}$ \\ Sekolah Tinggi Perikanan, Jurusan Penyuluhan Perikanan \\ Jalan Cikaret Nomor 2 Bogor 16001, Jawa Barat
}

Diterima: 12 Januari 2017; Disetujui: 2 April 2017

\begin{abstract}
Abstrak
Penelitian ini telah dilakukan mulai bulan April sampai Juli 2016 di Waduk Jatiluhur, Kabupaten Purwakarta. Tujuan Penelitian untuk mengetahui status kualitas perairan waduk Jatiluhur yang digunakan untuk budidaya Keramba Jaring Apung dan mengetahui beban limbah yang berasal dari keramba jarring apung. Diharapkan informasi ini dapat ditentukan kualitas perairan waduk jatiluhur dan apakah beban limbah yang berasal dari KJA sudah melampaui kapasitas asimilasi ekosistem waduk tersebut. Jenis data yang dikumpulkan terdiri dari data primer dan sekunder. Pengambilan sampel untuk kualitas air dilakukan pada beberapa stasiun yang mewakili daerah sekitarnya dan pengukuran parameter kualitas air dilakukan pada beberapa stasiun yang mewakili daerah sekitarnya dan pengukuran parameter kualitas air dilakukan secara in situ dan analisis di Laboratorium. Hasil penelitian menunjukkan bahwa status kualitas perairan waduk jatiluhur berdasarkan "US-EPA" adalah tercemar sedang hampir mendekati tercemar berat dengan nilai -30 kelas C. Beban limbah yang berasal dari keramba jarring apung ketika jumlah keramba yang ada sebanyak 30.000 petak keramba maka limbah Nitrogen dan Fosfor terlarut berturut-turut adalah 2722,65 ton/tahun, 22,40 ton/tahun. Sedangkan partikel Nitrogen dan Fosfor berturut-turut sebesar 418,87 ton/tahun dan 145,65 ton/tahun.
\end{abstract}

Kata Kunci: Beban limbah, Keramba Jaring Apung, Kualitas Air

\begin{abstract}
There have been two types of fishery running within the Jatiluhur reservoir, capture fisheries and aquaculture using floating cage nets for rearing fishes. To ensure the profability and sustainability of such an aquaculture business as well as preventing negative impacts of these aquaculture activities on the main functions of the reservoir as a source for irrigation and potable water, one of the most important things to do is making sure that aquaculture activities do not create pollution of the reservoir water ecosystem. Based upon the a forementioned background, this research has been conducted in the jatiluhur reservoir from April to July 2016. The objectives of this research were: (1) to determine the status of the reservoir's water quality, and (2) to estimate pollution load from floating cage net fish culture. It is expected that on the basis of these two sets of information, we can determine whether or not the existing pollution load from aquaculture activities has already exceeding the assimilative capacity of the reservoir water ecosystem. Primary data consist of water quality parameters and pollution load in the form of phosphor and nitrogen. In the meantime, secondary data were collected from various reports, books, and other sources of information. The pollution load originating from 30.000 floating cages in the form of dissolved nitrogen and phosphor are 2,722.65 tones/year and 22.40 tones/year respectively; and in the form of particulate nitrogen and phosphor are 418.87 tones/year and 145.65 tones/year respectively.
\end{abstract}

Keywords: Floating Nets Cage, Impact of Pollution, Water Quality

\footnotetext{
$\triangle$ Penulis korespondensi

Alamat surel: 16.dinno@gmail.com
}

Volume 11 Nomor 1 Tahun 2017 


\section{PENDAHULUAN}

Ekosistem perairan waduk terdiri dari komponen biotik seperti ikan, plankton, macrophyta, benthos dan sebagainya yang berhubungan timbal balik dengan komponen abiotik seperti tanah, air dan sebagainya. Waduk merupakan salah satu contoh perairan tawar buatan yang dibuat dengan cara membendung sungai tertentu dengan berbagai tujuan yaitu sebagai pencegah banjir, pembangkit tenaga listrik, pensuplai air bagi kebutuhan irigasi pertanian, untuk kegiatan perikanan baik tangkap maupun budidaya karamba. Dengan demikian keadaan waduk memberikan manfaat sendiri bagi masyarakat di sekitarnya.

Peningkatan pemanfaatan lahan di kawasan ini juga mendatangkan Peningkatan pemanfaatan lahan di kawasan ini juga mendatangkan dampak negatif terhadap habitat berbagai jenis plankton, ikan, hewan yang mendiami kawasan tersebut, nilai estetika dan fungsi utama dari tujuan pembuatan waduk itu sendiri.

Adanya kegiatan budidaya ikan dalam Karamba Jaring Apung (KJA) di Waduk Jatiluhur ini mengakibatkan terjadinya penurunan kualitas air waduk, pendangkalan waduk, dan lain-lain. Penyebab menurunnya kualitas air waduk, diduga karena banyaknya limbah organil sisa pakan budidaya KJA yang terbuang ke dalam perairan.

Sebagai kawasan industri berbasis budidaya KJA, salah satu aspek yang menjadi perhatian adalah manajemen pakan. Mendiami kawasan tersebut, nilai estetika dan fungsi utama dari tujuan pembuatan waduk itu sendiri.

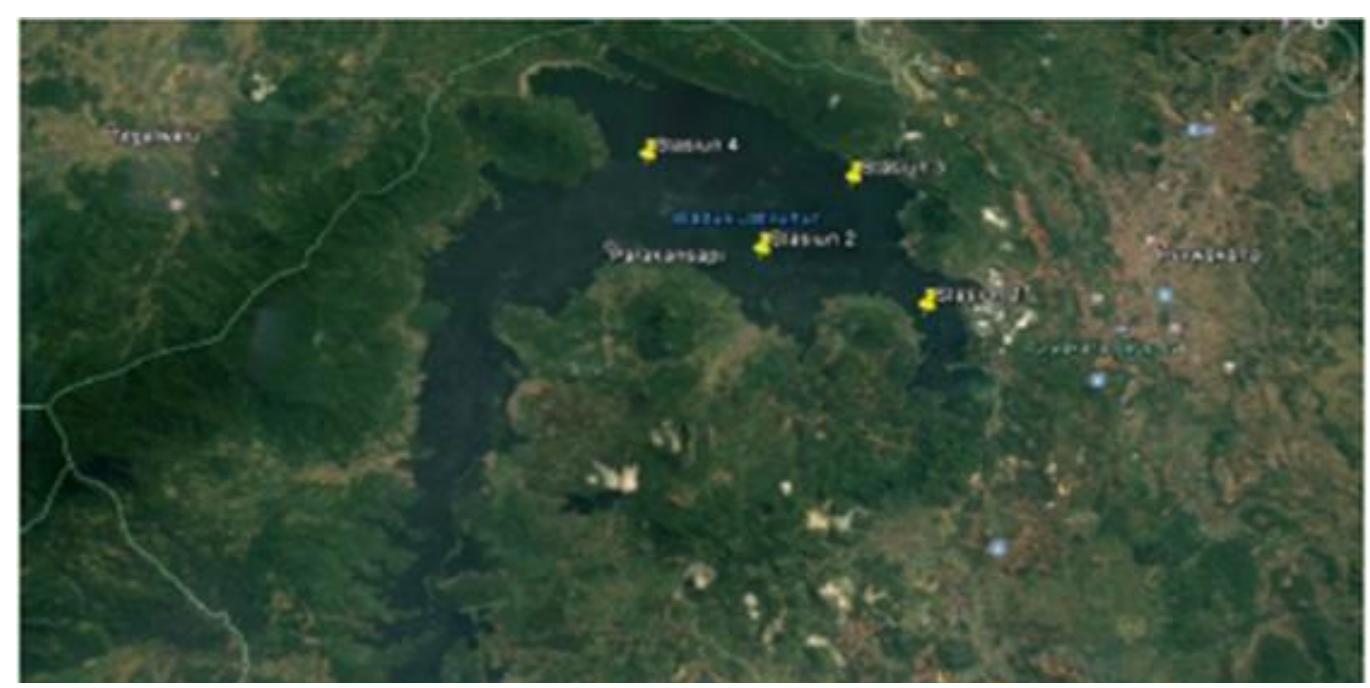

Keterangan lokasi:

- Stasiun 1: daerah dekat pemukiman

- Stasiun 2: daerah budidaya ikan karamba jaring apung (KJA)

- Stasiun 3: daerah genangan utama

- Stasiun 4: daerah dekat dengan inlet utama dari waduk Ir. H. Djuanda Jatilihur Gambar 1. Lokasi stasiun penelitian di Waduk Ir. H. Diuanda Jatiluhur Jurnal Penyuluhan Perikanan dan Kelautan 
Teknik pemberian jumlah dan dosis pakan yang agak kurang baik, berdampak terhadap berlebihnya sisa pakan yang mengakibatkan lingkungan perairan menjadi kurang baik (Sukadi, 2010). Kegiatan perikanan yang tidak ramah lingkungan seperti KJA yang melebihi daya dukung dari lingkungan maupun penggunaan pakan ikan akan meninggalkan sisa-sisa dari pakan yang menumpuk di dasar perairan selama bertahun-tahun. Hal ini menimbulkan pengkayaan unsur hara dan mempercepat eutroikasi yang selalu ditandai dengan berkembangnya jenis tanaman air seperti encek gondok, azola (Pujiastuti, 2013). Penelitian ini juga bertujuan untuk mengetahui status kualitas di perairan waduk jatiluhur yang digunakan untuk budidaya Keramba Jaring Apung dan beban limbah yang berasal dari kegiatan KJA.

\section{BAHAN DAN METODE}

Penelitian ini dilakukan pada perairan Waduk Jatiluhur, Jawa Barat selama 4 bulan mulai bulan April 2016 sampai dengan Juli 2016. Data-data yang digunakan dalam penelitian ini terdiri dari data primer dan data sekunder. Data primer diperoleh dengan cara pengukuran, pengamatan, dan wawancara dengan narasumber (pembudidaya dan instansi terkait) pada saat penelitian berlangsung. Data primer yang di kumpulkan adalah data kualitas air (kimia, fisika) dan data produksi guna menghitung produktivitas (jumlah panen / luas areal KJA) pada saat penelitian dilakukan. Data sekunder diambil untuk beberapa tahun terakhir yang meliputi data produksi dan jumlah KJA diperoleh dari instansi terkait sesuai dengan tujuan penelitian.

Tabel 1. Pedoman yang digunakan untuk mengetahui status mutu air dengan menggunakan metode STORET

\begin{tabular}{ccccc}
\hline \multirow{2}{*}{ Jumlah Contoh } & Nilai & \multicolumn{3}{c}{ Parameter } \\
\cline { 3 - 5 } & & Fisika & Kimia & Biologi \\
\hline$<10$ & Maksimum & -1 & -2 & -3 \\
& Minimum & -1 & -2 & -3 \\
& Rata-rata & -3 & -6 & -9 \\
& Maksimum & -2 & -4 & -6 \\
& Minimum & -2 & -4 & -6 \\
& Rata-rata & -6 & -12 & -18 \\
\hline
\end{tabular}


Tabel 2. Produksi ikan dari karamba jaring apung Kabupaten Purwakarta th.2010-2015

\begin{tabular}{cc}
\hline Tahun & Jumlah/Produksi \\
\hline 2010 & 88.629 Ton \\
2011 & 110.095 Ton \\
2012 & 110.631 Ton \\
2013 & 89.945 Ton \\
2014 & 92.165 Ton \\
2015 & 98.260 Ton \\
\hline
\end{tabular}

Pengambilan sampel dilakukan pada beberapa stasiun berdasarkan pertimbangan bahwa, stasiun yang ditetapkan dianggap mewakili daerah sekitarnya. Pada setiap stasiun dilakukan pengambilan air dilakukan dengan cara in situ dan analisis di laboratorium.

\section{Analisis Data}

Pedoman yang digunakan untuk mengetahui status mutu air adalah metode STORET (Tabel 1.)

Prinsipnya yaitu membandingkan antara data kualitas air dengan baku mutu air yang disesuaikan dengan peruntukkannya guna menentukan status mutu air adalah dengan menggunakan sistem nilai dari "US-EPA (Environmental Protection Agency)" dengan mengklasifikasi mutu air dalam empat kelas, yaitu :

(1) Kelas A: baik sekali, skor $=0$ (memenuhi baku mutu)

(2) Kelas B: baik, skor $=-1 \mathrm{~s} / \mathrm{d}-10$ (cemar ringan)
(3) Kelas C: sedang, skor $=-11 \mathrm{~s} / \mathrm{d}$ 30 (cemar sedang)

(4) Kelas D: buruk, skor $\geq-31$ (cemar berat)

Jumlah negatif dari data seluruh parameter dihitung dan ditentukan status mutunya dari jumlah skor yang didapat dengan menggunakan sistem nilai.

\section{Analisis Beban Pencemar}

Analisis data besarnya beban limbah yang berasal dari kegiatan KJA dilakukan dengan metode pendugaan total bahan organic (Marganof, 2007) dengan persamaan:

$$
O=T U X T F W
$$

Keterangan:

$\mathrm{O}=$ total output bahan organik partikel $\mathrm{TU}=$ total pakan yang tidak dikonsumsi $\mathrm{TFW}=$ total limbah feses

\section{HASIL DAN PEMBAHASAN}

Waduk Jatiluhur Purwakarta Jawa Barat merupakan salah satu dari sentra pembudidayaan ikan mas/nila terbesar di pulau jawa. Waduk Jatiluhur terletak di 
Kecamatan Jatiluhur, Kabupaten

Purwakarta $( \pm 9 \mathrm{Km}$ dari pusat kota Purwakarta). Bendungan ini menyediakan juga fungsi penyediaan air irigasi untuk 242.000 ha sawah (dua kali tanam dalam setahun), air baku, air minum, budidaya perikanan dan pengendali banjir yang dikelola oleh Perum Jasa Tirta II. Pembudidaya ikan di perairan Waduk Jatiluhur dengan menggunakan jaring terapung telah berlangsung selama beberapa tahun. Bagi penduduk yang tinggal di sekitar area waduk jatiluhur, budidaya ikan terutama ikan mas dan nila merupakan usaha favorit atau pilihan untuk memenuhi kebutuhan hidup bagi keluarga. Hal ini dikarenakan permintaan terhadap ikan mas tidak pernah sepi dan tingkat harga ikan mas yang relatif stabil di pasaran. Skala usaha budidaya KJA di waduk Jatiluhur berbeda-beda, tergantung dari besaran modal atau dana yang dimiliki pembudidaya KJA.

Kualitas perairan waduk Jatiluhur
Hasil pengukuran kualitas perairan Waduk jatiluhur disajikan pada Tabel 3. Suhu

Suhu air mempunyai pengaruh yang nyata terhadap proses pertukaran zat, suhu juga berpengaruh terhadap kadar oksigen terlarut dalam air, juga berpengaruh terhadap pertumbuhan dan nafsu makan ikan. Dalam berbagai hal, suhu berfungsi sebagai syarat rangsangan alam yang menentukan beberapa proses seperti migrasi, bertelur, metabolisme, dan lain sebagainya. Ikan dapat tumbuh dengan baik pada kisaran suhu $25-32^{\circ} \mathrm{C}$, tetapi dengan perubahan suhu yang mendadak dapat membuat ikan stress. Suhu air yang terukur pada perairan waduk jatiluhur masih dalam kisaran yang normal, yaitu $29-32^{\circ} \mathrm{C}$.

TSS

Total padatan tersuspensi (TSS) adalah padatan yang tersuspensi di dalam air berupa bahan-bahan organik dan anorganik yang dapat disaring dengan ke rtas milipore berpori-pori $0,45 \mu \mathrm{m}$. Materi

Tabel 3. Kualitas air di lokasi penelitian tahun 2016

\begin{tabular}{ccccc}
\hline Parameter & Stasiun 1 & Stasiun 2 & Stasiun 3 & Stasiun 4 \\
\hline $\mathbf{p H}$ & 8,1 & 8,3 & 8,3 & 7,4 \\
$\mathbf{S u h u}$ & 32 & 32 & 30 & 29 \\
$\mathbf{T S S}$ & 250 & 205 & 115 & 150 \\
$\mathbf{D O}$ & 4 & 4 & 4 & 5 \\
$\mathbf{C O D}$ & 13 & 15 & 29 & 17 \\
$\mathbf{B O D}$ & 6,4 & 6,3 & 14 & 9 \\
$\mathbf{N H}_{3}$ & 0,1 & 0,6 & 1,0 & 0,6 \\
$\mathbf{N O}_{\mathbf{2}}$ & 0,03 & 0,03 & 0,01 & $<0,004$ \\
$\mathbf{N O}_{3}$ & $<0,004$ & 0,1 & 0,04 & 0,1 \\
\hline
\end{tabular}


yang tersuspensi mempunyai dampak buruk terhadap kualitas air karena mengurangi penetrasi matahari ke dalam badan air, kekeruhan air yang meningkat, menyebabkan gangguan pertumbuhan bagi organisme produser. Kandungan total padatan tersuspensi yang terukur d perairan waduk jatiluhur yaitu sekitar 115-250 ppm.

\section{Derajat Keasaman}

Derajat keasaman merupakan gambaran jumlah atau aktivitas ion hidrogen dalam perairan derajat keasaman menunjukkan suasana air tersebut apakah masih asam ataukah basa. Secara umum nilai pH menggambarkan seberapa besar tingkat keasaman atau kebasaan suatu perairan. Perairan dengan nilai $\mathrm{pH}=7$ adalah netral, $\mathrm{pH}<7$ dikatakan kondisi perairan bersifat asam, sedangkan $\mathrm{pH}>7$ dikatakan kondisi perairan bersifat basa (Effendi, 2003). Derajat keasaman mempunyai pengaruh yang besar pada tumbuh-tumbuhan dan hewan air, sehingga sering dipergunakan sebagai petunjuk untuk menyatakan baik buruknya keadaan air sebagai ,lingkungan hidup biota air. Perubahan nilai $\mathrm{pH}$ perairan dapat dipengaruhi oleh beberapa faktor diantaranya adalah salah satu aktivitas fotosintesis, suhu serta buangan limbah. Nilai pH di perairan waduk jatiluhur berkisar: 7,4 - 8,3.

Oksigen terlarut
Oksigen terlarut merupakan salah satu parameter kimia air yang berperan pada kehidupan biota air. Penurunan oksigen terlarut dapat mengurangi efisiensi pengambilan oksigen bagi biota perairan, sehingga menurunkan kemampuannya untuk hidup normal. Menurut Lung (1993), kelarutan oksigen minimum untuk mendukung kehidupan ikan adalah sekitar 4 ppm. Nilai oksigen terlarut di perairan waduk jatiluhur adalah berkisar antara 4,05,0 ppm. Nilai tersebut masih mendukung kehidupan biota perairan yaitu minimum 4,0 ppm.

BOD

Biological oxygen demand (BOD) merupakan parameter yang dapat juga digunakan untuk menggambarkan keberadaan bahan organik di perairan. Hal ini disebabkan BOD dapat menggambarkan jumlah bahan organik yang dapat diuraikan secara biologis, yaitu jumlah oksigen terlarut yang dibutuhkan oleh mikroorganisme untuk memecahkan atau mengoksidasi bahan organic menjadi karbondioksida dan air.

Nilai BOD yang cukup tinggi menunjukkan semakin besarnya bahan organik yang terjadi terdekomposisi menggunakan sejumlah oksigen di perairan. Adapun nilai BOD di perairan waduk jatiluhur berkisar antara 6,3 - 14 $\mathrm{mg} / \mathrm{l}$. berdasarkan baku mutu air, nilai BOD 
yang dipersyaratkan 6 mg. $\mathrm{l}^{-1}$ (baku mutu sesuai peraturan Jawa Barat). Dengan demikian, disimpulkan bahwa perairan waduk jatiluhur tercemar oleh bahan organik yang mudah terurai (BOD).

COD

Chemical oxygen demand (COD) adalah nilai yang menggambarkan total oksigen yang dibutuhkan untuk mengoksidasi bahan organik secara kimiawi, baik yang dapat didegradasi secara biologi (biodegradable) maupun yang sukar didegradasi (non biodegradable) menjadi $\mathrm{CO}_{2}$ dan $\mathrm{H}_{2} \mathrm{O}$. Dari hasil analisis kualitas air di waduk jatiluhur menunjukkan bahwa nilai COD perairan berkisar antara 13-29 mg. $\mathrm{l}^{-1}$ berdasarkan baku mutu air yang mempersyaratkan nilai COD adalah 10 mg..$^{-1}$, maka perairan waduk jatiluhur tercemar oleh bahan organik yang sulit terurai.

\section{Nitrat}

Nitrat merupakan salah satu bentuk nitrogen yang larut dalam air. Pencemaran dari pemupukan, kotoran hewan dan manusia merupakan penyebab tingginya kadar nitrat. Hasil pengukuran kadar nitrat di perairan waduk jatiluhur berkisar antara $0.004-0.1 \mathrm{mg} .1^{-1}$. Secara umum, kandungan nitrat di perairan waduk jatiluhur berada di bawah baku mutu air, yang mensyaratkan kandungan nitrat untuk air baku maksimal $10 \mathrm{mg} . \mathrm{l}^{-1}$.
Dengan demikian disimpulkan bahwa perairan waduk jatiluhur tidak tercemar oleh senyawa nitrat.

\section{Nitrit}

Nitrit merupakan senyawa nitrogen beracun yang biasanya ditemukan dalam jumlah yang sangat sedikit (Marganof, 2007). Kandungan nitrit di perairan waduk jatiluhur berkisar antara $0.004-0.01 \mathrm{mg} . \mathrm{l}^{-1}$

- Baku mutu air kelas dua dan tiga mensyaratkan maksimal kandungan nitrit adalah 0,06 mg. $\mathrm{l}^{-1}$. Semua titik sampling pada perairan waduk jatiluhur mengandung nitrit yang tidak melebihi baku mutu.

\section{Amoniak}

Amoniak merupakan senyawa nitrogen yang berubah menjadi ion $\mathrm{NH}_{4}$ pada $\mathrm{pH}$ rendah. Amoniak berasal dari limbah domestik dan limbah pakan ikan. Ammonia di perairan waduk dapat berasal dari nitrogen organik dan nitrogen anorganik yang terdapat dalam tanah dan air berasal dari dekomposisi bahan organik oleh mikroba dan jamur. Selain itu, amoniak juga berasal dari denitrifikasi pada dekomposisi limbah oleh mikroba pada kondisi anaerob.

Ammonia juga dapat berasal dari limbah domestik dan limbah industri (Marganof, 2007). Hasil analisis kualitas air menunjukkan kadar ammonia di perairan waduk jatiluhur berkisar antara

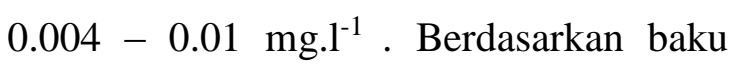
mutu air mensyaratkan kandungan 
ammonia maksimal $0,02 \mathrm{mg} \cdot \mathrm{l}^{-1}$. Dengan demikian dapat disimpulkan bahwa perairan waduk Jatiluhur tercemar ammonia.

\section{Status mutu air}

Untuk menentukan status mutu air adalah dengan menggunakan sistem nilai dari "US EPA (Environmental Protection Agency)" dengan juga mengklasifikasikan mutu air dalam empat kelas, yaitu:

(1) Kelas A: baik sekali, skor $=0$ (memenuhi baku mutu)

(2) Kelas B: baik, skor $=-1 \mathrm{~s} / \mathrm{d}-10$ (cemar ringan)

(3) Kelas C: sedang, skor $=-11 \mathrm{~s} / \mathrm{d}-30$ (cemar sedang)

(4) Kelas D: buruk, skor $\geq-31$ (cemar berat)

Berdasarkan perhitungan diaatas, nilai STORET (-30) PERAIRAN WADUK Jatiluhur tercemar sedang.

\section{Pendugaan Beban Limbah}

Berdasarkan data laporan dari Dinas

Perikanan Kabupaten Purwakarta jumlah
KJA yang terdapat di perairan Jatiluhur sebanyak \pm 30.000 petak yang dipasang pada seluruh kawasan zona budidaya waduk Jatiluhur (Tabel 2). Pada KJA tersebut dibudidayakan ikan mas dan nila merah. Budidaya ikan nila pada umumnya dilakukan bersamaan dengan ikan mas. Para pembudidaya pelihara nila dibawah jarring ikan mas.

Sistem ini dikenal dengan sebutan sistem "kolor", dengan tujuan untuk memanfaatkan pakan yang tidak dimakan oleh ikan mas dengan melihat rata-rata produksi ikan dari karamba jarring apung Kabupaten Purwakarta dari tahun 2010 2015 adalah 98.287 ton/tahun untuk tiga siklus sehingga per petak budidaya menghasilkan 1.09 ton/siklus. Estu Nugroho (2011) dalam penelitiannya menyebutkan bahwa rata-rata ratio konversi pakan (FCR) budidaya ikan di waduk Jatiluhur adalah 1:1,11. Dengan demikian jumlah pakan yang diberikan sebanyak 109.098 ton untuk 30.000 petak.

Tabel 4. Status mutu kualitas air menurut sistem nilai STORET

\begin{tabular}{|c|c|c|c|c|c|c|c|}
\hline No & Parameter & Satuan & $\begin{array}{l}\text { вaku } \\
\text { Mutu }\end{array}$ & Maksimum & Minimum & Rata'Rata & Skor \\
\hline 1 & $\mathrm{pH}$ & & $6-9$ & 8,3 & 7,4 & 7,85 & \\
\hline 2 & Suhu & ${ }^{\circ} \mathrm{C}$ & & 32 & 29 & 30,5 & \\
\hline 3 & TSS & $\mathrm{Mg} / 1$ & 1000 & 250 & 115 & 182,5 & \\
\hline 4 & DO & $\mathrm{Mg} / 1$ & $>3$ & 5 & 4 & 4,5 & \\
\hline 5 & $C O D$ & $\mathrm{Mg} / 1$ & 10 & 29 & 13 & 21 & -10 \\
\hline 6 & BOD & $\mathrm{Mg} / 1$ & 6 & 14 & 6,3 & 10,15 & -10 \\
\hline 7 & $\mathrm{NH}_{3}$ & $\mathrm{Mg} / 1$ & 0.02 & 1 & 0,1 & 0,55 & -10 \\
\hline 8 & $\mathrm{NO}_{2}$ & $\mathrm{Mg} / 1$ & 0.06 & 0.03 & 0.004 & 0,017 & \\
\hline 9 & $\mathrm{NO}_{3}$ & $\mathrm{Mg} / 1$ & 10 & 0,1 & 0,004 & 0.052 & \\
\hline Total & & & & & & & -30 \\
\hline
\end{tabular}


Tabel 5. Beban limbah yang berada dalam bentuk terlarut dan dalam bentuk partilel

No Terlarut

\section{Partikel}
$1 \quad 65 \% \mathrm{~N}=2722,65$ ton $/$ tahun
$10 \% \mathrm{~N}=418,87$ ton $/$ tahun
2
$10 \% \mathrm{P}=22,40$ ton $/$ tahun
$65 \% P=145,65$ ton $/$ tahun

Pada budidaya ikan secara intensif, jumlah pakan diberikan sebanyak 30\% tertingggal sebagai sisa pakan yang tidak dimakan konsumsi dan 25-30\% pakan yang dikonsumsi akan diekskresikan (McDonald et al., 1996).

Petani KJA menggunakan pakan (pellet) dengan kandungan protein $18 \%$. Untuk menentukan kandungan nitrogen dan fosfor yang terdapat dalam pakan, dilakukan dengan suatu perkalian antara jumlah pakan (JP) yang diberikan dengan konstanta pakan $(\mathrm{N}=4,86 \%$ dan $\mathrm{P}=$ 0,26\%) (Nastiti et al., 2001 dalam Marganor, 2007). Dengan demikian, jumlah nitrogen dan fosfor yang terkandung dalam pakan yang diberikan pada kegiatan KJA di Waduk Jatiluhur adalah $\mathrm{N}=5302,16$ ton dan $\mathrm{P}=283,65$ ton. Dari pakan yang diberikan tersebut hanya $70 \%$ yang dimakan oleh ikan, dan sisanya sebanyak 30\% akan lepas ke badan perairan waduk sebagai bahan pencemar atau limbah (Rachmansyah, 2004; Syandri, 2006 dalam Marganof, 2007). Sementara itu 15-30\% dari nitrogen $(\mathrm{N})$ dan fosfor $(\mathrm{P})$ dalam pakan akan diretensikan dalam daging ikan dan selebihnya dibuang ke badan perairan danau (Beveridge, 1987; Avnimelech, 2000 dalam Marganof, 2007; serta Pujiastuti dkk, 2013). Dengan demikian dapat ditentukan jumlah beban limbah nitrogen $(\mathrm{N})$ dan fosfor $(\mathrm{P})$ dari kegiatan KJA yang masuk ke badan perairan Waduk Jatluhur yaitu nitrogen sebesar nilai 4188,70 ton per tahun, dan fosfor sebesar 224,08 ton per tahun.

Beban limbah yang masuk ke badan perairan Waduk Jatiluhur tersebut, menurut Midlen dan Redding (2000) dalam Marganof (2007), serta Pujiastuti dkk (2013) yang berada dalam keadaan/bentuk terlarut dan dalam keadaan/bentuk partikel, sebagaimana terlihat Tabel 5.

Sisa pakan dalam bentuk partikel ini akan mengendap menjadi sedimen di dasar perairan Waduk Jatiluhur. Input nutrient ke badan air yang berlebih akan dapat meningkatkan konsentrasi nutrient dan terjadi peledakan populasi fitoplankton.

Disamping itu, tingginya kandungan bahan tersebut mengakibatkan adanya suatu peningkatan terhadap rendahnya tingkat oksigen terlarut pada area yang luas, tingginya kandungan BOD 
Tabel 6. Perkiraan beban pencemar dalam bentuk organik dari kegiatan penggemukan ikan di waduk Cirata; dalam satuan ton /tahun.

\begin{tabular}{|c|c|c|c|c|c|c|}
\hline \multirow[t]{2}{*}{ Waduk } & \multirow{2}{*}{$\begin{array}{l}\text { Jumlah } \\
\text { keramba } \\
\text { (unit) }\end{array}$} & \multirow{2}{*}{$\begin{array}{l}\text { Perkiraan } \\
\text { produksi } \\
\text { pertahun }\end{array}$} & \multicolumn{3}{|c|}{$\begin{array}{l}\text { Perkiraan Limbah } \\
\text { Ton tahun }\end{array}$} & \multirow[t]{2}{*}{$\begin{array}{l}\text { Keterangan } \\
\text { diolah dari : }\end{array}$} \\
\hline & & & Organik & $\mathrm{N}$ & p & \\
\hline Saguling & 4.425 & 8.762 & $\begin{array}{l}10.952 \\
(31.3)\end{array}$ & $\begin{array}{l}478 \\
(1.3)\end{array}$ & $\begin{array}{c}68 \\
(0,19)\end{array}$ & $\begin{array}{l}\text { UPTD Saguling. } \\
\quad \text { Cirata }\end{array}$ \\
\hline Cirata & 28.738 & 118,082 & $\begin{array}{l}148.782 \\
(543,50)\end{array}$ & $\begin{array}{l}8.667 \\
(23,7)\end{array}$ & $\begin{array}{l}1.239 \\
(3.39)\end{array}$ & Gamo \& Adibroto \\
\hline Jatiluhur & 2.537 & 2.500 & $\begin{array}{l}3.125 \\
(8.6) \\
\end{array}$ & $\begin{array}{r}136 \\
0.37) \\
\end{array}$ & $\begin{array}{c}19 \\
(0,05)\end{array}$ & Sukimin dkk., \\
\hline
\end{tabular}

konsentrasi ammonia di dalam kolom perairan (Werren, 1982).

Beban limbah budidaya yang terbuang ke dalam badan air memberi sumbangan dari bahan orgamik yang menyebabkan pengkayaan nutrien dan bahan organik hingga mempengaruhi tingkat kesuburan dan kelayakan kualitass air bagi kehidupan ikan budidaya. Berdasarkan publikasi yang ada beban pencemar organic dari KJA pada seperti Tabel 6. (Garno, 2001).

Belakangan ini muncul wacana untuk meniadakan karamba jarring apung di Waduk Jatiluhur, namun hal ini tidaklah mudah untuk dilakukan mengingat banyaknya efek yang ditimbulkan untuk masyarakat umum, pembudidaya ikan, pedagang benih, pedagang pakan, transportasi dan yang lainnya, sehingga diperlukan kebijakan pengelolaan waduk yang tidak akan merugikan masyarakat setempat maupun lingkungan ekosistem waduk. Berdasarkan peraturan Gubernur, hanya $1 \%$ dari luas waduk yang boleh digunakan untuk budidaya perikanan.

Penataan KJA dalam arti mengurangi jumlah yang ada saat ini tidak bisa dihindari. Dengan luasan yang 8300 ha, maka untuk Waduk Jatiluhur maksimal 83 ha saja yang boleh digarap untuk budidaya, luasan tersebut untuk ukuran ideal budidaya hanya memuat 16.938

Tabel 7. Beban limbah vang berada dalam bentuk terlarut dan dalam bentuk partikel

No Terlarut Partikel

\begin{tabular}{lcc}
\hline 1 & $65 \% \mathrm{~N}=1534,26$ ton $/$ ahum & $10 \% \mathrm{~N}=236,04$ ton/tahun \\
2 & $10 \% \mathrm{P}=12,62$ ton t thum & $65 \% \mathrm{P}=82,03$ ton'tahum \\
\hline
\end{tabular}


petak. Sehingga jika skenario ini diterapkan maka produksi ikan karamba jarring apung waduk Jatiluhur Kabupaten Purwakarta adalah 55.387,26 ton/tahun. Dengan demikian jumlah pakan yang diberikan sebanyak $61.479,8$ ton. Jumlah $\mathrm{N}$ dan $\mathrm{P}$ yang terkandung dalam pakan yang diberikan pada kegiatan KJA di Waduk Jatiluhur adalah $\mathrm{N}=2987,9$ ton dan $\mathrm{P}=$ 159,8 ton. Sehingga jumlah beban limbah nitrogen $(\mathrm{N})$ dan fosfor $(\mathrm{P})$ dari kegiatan KJA yang masuk ke badan perairan Waduk Jatiluhur yaitu $\mathrm{N}$ sebesar 2360,4 ton per tahun dan $\mathrm{P}$ sebesar 126,2 ton per tahun. Beban limbah yang masuk ke badan perairan Waduk Jatiluhur tersebut yang berada dalam keadaan/bentuk terlarut dan dalam keadaan/bentuk partikel dapat dilihat pada table 7 .

\section{SIMPULAN DAN SARAN}

\section{Simpulan}

1. Berdasarkan hasil perhitungan dengan menggunakan sistem nilai dari "USEPA (Environmental Protection Agency)", nilai STORET (-30) maka perairan Waduk Jatiluhur tercemar sedang;

2. Perbandingan jumlah beban limbah nitrogen $(\mathrm{N})$ dan forfor $(\mathrm{P})$ dari kegiatan KJA yang masuk ke dalam badan perairan Waduk Jatiluhur adalah sebagai berikut: a. Pada kondisi jumlah karamba sebanyak 30.000 petak, maka jumlah beban limbah nitrogen dan fosfor dari kegiatan KJA yang masuk ke badan perairan Waduk Jatiluhur yaitu Nitrogen sebesar 4188,70 ton pertahun dan Fosfor sebanyak 224,08 ton per tahun. Keadaan terlarut fosfor $(\mathrm{P})$ sebesar 22,40 ton dan nitrogen $(\mathrm{N})$ sebesar 2722,65 ton, dan yang berada dalam bentuk partikel adalah fosfor $(\mathrm{P})$ 145,65 ton dan nitrogen $(\mathrm{N})$ sebesar 418,87 ton.

b. Sedangkan pada kondisi jika skenario pengurangan jumlah karamba diterapkan menjadi sebanyak 16.938 petak adalah jumlah beban limbah nitrogen $(\mathrm{N})$ dan fosfor $(\mathrm{P})$ dari kegiatan KJA yang masuk ke badan perairan Waduk Jatiluhur yaitu nitrogen sebesar 2360,4 ton per tahun, dan fosfor sebesar 126,2 ton per tahun, yang berada dalam keadaan terlarut adalah fosfor (P) 12,62 ton dan nitrogen $(\mathrm{N})$ sebesar 1534,26 ton yang berada dalam bentuk partikel adalah fosfor (P) 82,03 ton dan nitrogen $(\mathrm{N})$ sebesar 236,04 ton.

\section{Saran}

Dalam pengelolaan lingkungan yang berkelanjuan serta dapat memberikan manfaat bagi masyarakat terutama masyarakat perikanan, diperlukan 
kebijakan pengelolaan waduk yang tidak merugikan masyarakat maupun lingkungan ekosistem waduk dengan cara meerapkan peraturan pemanfaatan waduk sebesar $1 \%$ dari luasan waduk yang ada untuk kegiatan perikanan yaitu sebesar 83 ha atau karamba sebanyak 16.938 petak.

\section{DAFTAR PUSTAKA}

Amidarhana A. 2001. Analisis produktifitas usaha budidaya ikan karamba jarring apung di Waduk Jatiluhur Kabupaten Purwakarta Provinsi Jawa Barat. Fakultas Perikanan dan Ilmu Kelautan, IPB.

Fardiaz S. 1992. Polusi Air dan Udara, Penerbit Kanisius, Yogyakarta. Hal: 21-23, 185

Garno YS. 2001. Status dan Karakteristik Pencemaran di Waduk Cascade Citarum. Jurnal Teknologi Lingkungan, Vol. 2 (2), Mei 2001: 207-213

Garno YS. 2003. Status Kualitas Perairan Waduk Juanda. Jurnal Tek ling, P3TL-BPPT.4 (3): 128-135

Hardjamulia A, N Suhenda, Krismono. 1991. Budidaya Ikan Air Tawar dalam Keramba Jaring Apung Mini. Pusat Penelitian dan Pengembangan Perikanan Jakarta.
Hidayat I. 1981. Water pollution control, pengawasan kualitas dan pencemaran air, Paket Ilmu Jurusan Farmasi, FMIPA, ITB, BPC, I.S.F.I, Jwa Barat. Hal : 12-14

Marganof. 2007. Model Pengendalian pencemaran perairan di Danau Maninjau Sumatra Barat. IPB. Bogor. McDonlad M.E, CA Tikkanen. ${ }^{45}$ Axler CP Larsen and G : 1996. Fish simulation culture model (fis-c): a bioenergetics based model for aquacultural wasteload application Aquacultural Engineering, 15 (4): 243-259.

Nugroho E. 2011. Kajian lapang budidaya karamba jaring apung ikan nila "mandiri" di Waduk Cirata dan Jatiluhur, Balai Riset Perikanan Budidaya Air Tawar, Media Akuakultur Vol. 6 (1) tahun 2011.

Odum EP. 1993 Dasar-dasar ekologi edisi ketiga, Gajah Mada Universitas Press. Yogyakarta.

Pujiastuti P, Ismail B, Pranoto. 2013. Kualitas dan beban pencemaran perairan Waduk Gajah Mungkur. Jurnal EKOSAINS Vol. V (1)

Ruding SO, W Rush (Editor). 1989. The Control Of Eutrophication of Lakes and Reservoirs. The Parthenon Publishing Group. Paris.

Simarmata AR. 2007. Kajian keterkaitan antara cadangan oksigen dengan 
beban masukan bahan organik di Waduk Ir. H Djuanda Purwakarta, Jawa Barat (Tesis), Bogor : IPB.

Suhadi MF. 1989. Petunjuk teknis budidaya ikan dalam karamba jaring apung. Badan Penelitian dan Pengembangan Pertanian. Pusat Penelitian dan Pengembangan Perikanan. Jakarta.

Sukadi MF. 2010. Ketahanan dalam air dan pelepasan nitrogen dan fosfor ke air media dari berbagai pakan ikan air tawar. Jurnal. Ris. Akuakultur, 5 (1):01-12.

Warren HI, 1982. Evaluation of matter discharged from trout farming in Denmark. Report of the EIFACT Workshop on Fish Farm Effluents, FAO/EIFACT Technology P 41:5763. 